\title{
Local links, local knowledge: Choosing care settings and schools
}

\section{Carol Vincent, Annette Braun and Stephen Ball, Institute of Education, University of London}

Dr Carol Vincent,

Centre for Critical Educational Policy Studies (CeCeps)

Institute of Education,

20 Bedford Way

London WC1H OAL.

Email: c.vincent@ioe.ac.uk 


\title{
Local links, local knowledge: Choosing care settings and schools
}

\begin{abstract}
This paper draws on data from two recently completed ESRC-funded projects in order to examine class differences and similarities around choice of school and choice of childcare. We argue here that there is every reason to believe that in many circumstances, within its particular mechanisms and practices, choice produces specific and pervasive forms of inequity.The processes by which working class parents in one study chose care settings and schools could be seen as less skilled, less informed, less careful than the decision-making of many of the middle class respondents. However, this is not an argument we advance, noting instead that the practices and meanings of choice are subject to significant social, cultural and economic variations in terms who gets to choose, who gets their choices, and what, how and why people choose when they are able to. We argue here that there are alternative sets of priorities in play for our working class respondents, involving attachments to the communal and the local.
\end{abstract}

Keywords: choice, childcare, social class 


\section{Local links, local knowledge: Choosing care settings and schools}

\section{Introduction}

In this paper we draw primarily on data collected as part of a recently completed ESRC-funded project (RES 000230770), which investigated the interactions of working class parents in London, England, with pre-school childcare. This particular paper focuses on the choices of care setting and primary school made by our respondent parents. The project is both an extension and a continuation of earlier work (R000239232) also referred to here, with middle class parents from the same London localities, analysing their experiences of the childcare market. Thus, in the first half of this paper, we draw comparisons between the ways in which middle and working class parents engage with childcare settings, exploring their interactions with both local markets. In the second half of the paper, we focus on the working class parents' choice of school, and illustrate the importance of local connections for parents in their identification of a primary school. We conclude by examining the role of choice in the social reproduction and social mobility of these working class families.

\section{The childcare research projects}

In this section, we wish to offer the reader a brief insight into how data was collected and analysed for the two projects. The constraints of space prevent us from offering much detail, but a more comprehensive account of the middle class project is offered in Vincent \& Ball 2006; similar methods of analysis were employed in the second project.

Both research projects are located within two inner London areas, one, Stoke Newington in the borough of Hackney in North London and the second, Battersea, in the borough of Wandsworth in South London. The first project (2001-4) focused on middle class parents' experiences of the childcare market. The research involved a respondent group of 57 mothers and 14 fathers (from 59 families). We also interviewed carers, although this paper draws primarily from the interviews with parents. The parent group were mostly white (except 3), mostly in heterosexual partnerships (except 1), and all highly educated, (to degree level, with $46 \%$ of mothers and $37 \%$ of fathers having postgraduate qualifications). In general the parents 
were in their 30s and 40s. These families were over-whelmingly owner occupiers, a few rented privately and no-one lived in public sector housing. The respondents were recruited in a number of ways: we placed adverts in child friendly shops and cafes in the areas and in local area parenting newsletters and those of the National Childbirth Trust. We also attended mother and toddler groups and activities in order to make contact with parents.

The primary focus of this paper is the second project (2005-7), which explored the engagement of working class families with childcare. The parent respondents came from 70 families (34 in Stoke Newington and 36 in Battersea). Again, the majority of the initial interviews were with mothers (61), three were with fathers and six with couples. We also conducted repeat interviews with 20 families, of which eight included both partners. This gave a total of 98 interviews. The working class parents were far more heterogeneous than the respondents in the middle class project. All had children under 5 years, but were otherwise very diverse on several indicators, such as number of children, family structure, occupational status, educational qualifications and ethnic background. For example, respondent mothers were aged between 16 and $40+$, and 29 were lone mothers. The 35 mothers working outside the home did so in occupations ranging from routine to lower managerial (please see appendix). Families had diverse ethnic backgrounds, we classified 29 mothers as being White UK or White Other, 27 as having African/Caribbean origins and ten as coming from an Asian background. Most of the families lived in public sector housing (39), others lived with family (13) and six of the families owned their own home. We again employed a range of strategies to meet respondents: we visited and spent time in five local authority and voluntary sector nurseries in the two localities and attended Sure Start groups/activities. We also went to playgroups and toy libraries in diverse community settings.

In both projects, interviews took from between 45 minutes to two hours, and were fully recorded and transcribed. In all cases parents were given the choice of setting (their home, their workplace, a café or similar, or the childcare setting (in those cases 
where the nurseries could provide us with private space) ${ }^{1}$. There is an interesting set of issues around researcher-respondent relationships, especially considering the class differences amongst the two samples. The majority of the interviews were conducted by white middle class women ${ }^{2}$, and the potential ramifications of this class similarity with the middle class mothers are discussed in Vincent \& Ball (2006). We hope to produce a similar set of reflections concerning the working class project in due course. We analysed the data in two main ways. i) NVivo was used for data management and search purposes. These searches were used to bring together theme and topic data which were then subject to detailed hand-coding. ii) Hand-coding was employed as a means to identify and examine key themes and issues. This was begun early in the research process and, in both projects involved all members of the research team, which provided a basis for coding reliability. We built up a portfolio of themes and issues which was subject to continuing review and revision. Careful comparisons were undertaken within the data and a fine-grained examination of particular themes, such as mothering, communication with carers, fathers' roles, future plans and aspirations, was conducted. As part of this, a variety of 'counts' were also undertaken (e.g around 'willing' school choice) which were related back to other factors such as occupational status. A combination of the identified themes and issues and the counts were the basis for selecting interview quotations for inclusion in this text. Those selected are representative but also illustrative in as much that it is impossible to include anything like a full qualitative data set in a paper of this length. The quotations in each case stand for a whole range of other examples that were categorised within the same theme.

\section{Choice}

Since the 1980s, in the UK and elsewhere, consumer choice has become a fundamental, orienting public sector reform. We would like to introduce this section with a quotation from Mark Olssen, which describes the formation of the consumer self under neo-liberalism.

\footnotetext{
${ }^{1}$ We are unable to discern any differences in the interview data related to the setting in which the interview took place.

2 The interviewers for the middle class project include Carol Vincent, Stephen Ball, Sophie Kemp and Soile Pietienkin; for the working class project, Annette Braun, Clare Frost and Carol Vincent.
} 
In neo-liberalism the state seeks to create an individual who is an enterprising and competitive entrepreneur...The shift from classical liberalism to neo-liberalism involves a change in subject position from 'homo economicus' who naturally behaves out of self interest and is relatively detached from the state, to 'manipulatable man' who is created by the state and who is continually encouraged to be "perpetually responsive'. It is not that the conception of the self-interested subject is replaced or done away with by the new ideals of neo-liberalism, but that in the age of universal welfare, the perceived possibilities of slothful indulgence create necessities for mew forms of vigilance [and] surveillance. In this model, the state has taken it upon itself to keep us all up to the mark. The state will see to it that each one of us makes a 'continual enterprise of ourselves' (Gordon, 1991) (Olssen 1996 p.340)

This description seems to resonate with Suzannah's account of her choice making decisions with regard to childcare and schooling.

I was just getting over the childbirth thing and venturing out of the house and people said, 'so, what schools?' And I just thought, but she's a little baby, but you have to put them down. I sort of got panicky, then I researched it. I brought the books, 'The Top 500 Schools' and you just read, and obviously area, and you just try and dwindle it down...so I was ringing round when [daughter] was five months old for an [independent ] school at 4, and then I worked backwards....What I did was speak to the admission secretary and said 'which [nursery] school do you find that seems to have a similar way of teaching?', and they give you a list. They can't recommend, all they can say is statistically speaking we get 6 from [child's current nursery school ] and 5 from [competitor nursery] (Suzannah, white with partner, Stoke Newington (SN)

Suzannah was a respondent in our middle class project. Her skilled and knowledgeable planning, designed to attain places for her daughters at a highly selective girls school was not mirrored to this degree by all our middle class 
respondents. However, nor was she alone amongst the middle class respondents in her strategizing. She is, of course, acting outside the state, concentrating her efforts exclusively in the private sector. However, despite this, she is, we suggest, a good example of Olssen description. She is an informed and active consumer of care and education services. As Clarke notes she is a 'self-directing individual agent encountering a multiplicity of possibilities created by many providers' (Clarke et al, 2006 p. 327). Rescued from potential 'sloth' by people around her, she swallows her emotional responses (her surprise that she 'has' to act so soon and her panic that she might be too late), accepts her individualized responsibility, collects information, and then makes strategic, rational decisions with regard to childcare that will maximize the chances of seeing her choice of school realized.

It is also important to note that despite Olssen's phrase 'manipulatable man', she is, of course, female, and research shows the extent to which women take a lead role in choice of education and childcare (David 1993, Gewirtz et al 1995, Ball 2003, Vincent \& Ball 2006). A common pattern in relation to childcare across our working class and middle class respondents, was that the mother identified potential care settings, collected information and then the father accompanied her on a visit to the preferred setting $(\mathrm{s})^{3}$. We have discussed elsewhere the somewhat limited role in terms of childrearing that many of our fathers adopted, acting as ancillaries to the mothers (Vincent \& Ball 2006 ch. 5, Braun et al 2008, see also Dermott 2008).

To return to choice, it is important to keep reminding ourselves that it is a contestable and indeterminate concept, open and empty and generic and encompasses a wide range of actions. Despite the massive body of research on school choice which exists world-wide it is still possible for advocates of choice to assert the abstract simplicities of choice, 'choice-in-general' as John Clarke puts it, as a means to promote greater equity. Thus Michael Barber in an interview with the New York Times (13/01/2006), asserted that: 'Since the status quo is inequitable there is every reason to believe that extending choice to everyone should produce greater equity'. We argue here that there

\footnotetext{
${ }^{3}$ The overwhelming majority of respondents across our two studies were women, but we did speak to a small number of men (14 in the middle class study and 16 in the working class study) and so have retained the term 'parent' here in our discussion of the families.
} 
is every reason to believe that in most, not all but most, circumstances, within its particular mechanisms and practices, choice produces new forms of inequity.

In describing and analysing the choice making behaviour of working class parents, we seek to make the argument that Suzannah's behaviour should not be taken as offering a normative standard. The processes by which working class parents in our second study chose care settings and primary schools could be seen as less skilled, less informed, less careful than many of our middle class respondents, thus positioning them as inadequate consumers - and parents. However, the practices and meanings of choice are subject to significant social, cultural and economic variations in terms who gets to choose, who gets their choices, and what, how and why people choose when they are able to. We argue here that there are alternative sets of priorities in play for our working class respondents, involving attachments to the communal and the local.

\section{Choosing childcare}

We have been researching childcare choice since a pilot study in 1999. In that time there has been a massive expansion of state-funded provision, which has served to reframe childcare as an issue for public policy, rather than a private issue to be resolved by individual women wishing to re enter the labour market. Any comparison between the current scope of, concern with, and investment in childcare, with what the Daycare Trust has described as 'that childcare desert of the 1980s' (Annual Review 2007), clearly reveals the progress made ${ }^{4}$. However, the Labour Government remains committed to a consumerist role for parents, and a 'mixed economy' of provision in childcare (Lewis 2003). We show here, drawing on our research data, that differently positioned families understand and experience childcare markets in very different ways.

The childcare market is not the classical market of neo-liberal theory. Rather, it is a highly regulated market, regulated in terms of provision by Ofsted, and also regulated in terms of subsidies offered to lower income parents. As part of the Labour government's efforts to encourage women back into the labour market, tax credits

\footnotetext{
${ }^{4}$ A considerable body of research in the UK, USA and elsewhere, argues that quality provision in terms of early years education and care has important benefits in the child's later life, particularly where children from disadvantaged families are concerned (e.g. Heckman \& Masterov 2007, Berlinski, Galiani \& Manacorda 2008, Sylva et al 2008, Wossmann 2008).
} 
were devised to allow lower income families to access childcare (generally recognised as very expensive in the UK, with parents bearing $70-75 \%$ of costs). In London, the Childcare Affordability Programme (CAP) offers a further subsidy for low income parents, paid directly to the provider. Interestingly although our respondents in the working class project frequently discussed tax credits, no parents mentioned the CAP. This may be because parents did not differentiate between benefits. This significant degree of intervention into the childcare market has been aimed at making childcare provision easier to access. Certainly many of our working class respondents, despite their misgivings about the administration of tax credits, commented that tax credits made it financially worth their while to return to work. The direction of the Labour government's intervention is supported by several economists researching childcare argue for the use of targeted subsidies to help low income families access childcare (e.g. Lowe \& Weisner 2004, Chevalier et al 2006, Heckman \& Masterov 2007). However, our primary focus in this part of the paper is not the effectiveness of subsidies, but rather the neo-liberal notion of choice: what degree of choice of childcare do parents possess or are willing to activate?

Simon Duncan and colleagues argue that believing people make decisions around childcare and paid work in an individualistic and impersonal fashion is a 'rationality mistake'. Research on choice, such as ours and that of Simon Duncan and colleagues (e.g. Duncan et al 2003, Carling et al 2002, Lowe \& Weisner 2004, Meyers \& Jordan 2006) show that parental decisions around childcare are a complex mixture of practical and moral concerns, social relations are as least as important as economic relations. To consider themselves as purely actors in the labour market, a stance Duncan et al term the 'adult worker model' would be a highly limited and limiting strategy, allowing 'little consideration of the wider social, moral and emotional components of parenting or childcare' (Duncan et al 2004, p.255). 'People do not act in an individualistic economically rational way. Rather they take such decisions with reference to moral and socially negotiated views about what behaviour is right and proper, and this varies between particular social groups, neighbourhoods and welfare states' (Duncan et al 2004 p.256).

It is an obvious but important point that choice is not unfettered. In the current 'mixed economy' of provision, our working class and middle class respondents could access 
very different types of care, had very different 'circuits' (Ball et al 1995) of provision available to them, thereby illustrating the degree of segregation at the heart of the childcare market in inner London. Our first project on middle class parents' use of childcare describes a complex and dynamic market, with informed and active consumers. Providers included day nurseries, nursery schools and nursery classes in both the private and state sectors, childminders and nannies. However, the nature of the childcare market as experienced by working class parents in our second study is far more uniform in terms of provision, and low key in terms of consumer activity With one exception, public provision is used by these families, whilst the middle class families mostly chose amongst a large range of private providers (also McKie et al 2001). The working class parents had little contact with the private sector; in Stoke Newington, they used local authority-run nurseries, and in Battersea, state provision run by a voluntary organisation. There was a Sure Start local programme in each area which targeted some activities at specific social groups (e.g. Muslim women). The five nursery settings we visited for the working class project, shared a number of similarities in terms of their provision and practices, contrasting with the broader range of pedagogies apparent in the private nurseries visited for the middle class project (see Vincent \& Ball 2006 ch. 6). For example, Montessori provision was frequently used and mentioned by middle class parents but only by one working class mother, who had briefly used a Montessori-influenced nursery belonging to a charitable trust.

The details of making choices were superficially similar for both groups. Both sets of parents obtained lists from local authorities, and visited settings that they could practically incorporate into their daily timetables. Both groups were heavily influenced by their affective responses to settings, their 'gut instinct' about both physical settings and the carers themselves. The middle class respondents with the resources to be able to access a wider range of settings, often visited four or five providers, and in the process, sometimes changed their minds about which type of provider - childminder, nanny or nursery - they wanted (see below). Some had clearer ideas and were more demanding than others. Nancy, for instance, is a highly active middle class chooser seeking a nanny, a process in which she interviewed 'forty or fifty' different candidates. The working class parents were particularly constrained in the choice of carer by cost and by the practicalities of getting to the 
nursery and then onto work. They chose nurseries from the list provided by the council, or approached nurseries they knew existed in the area. In some cases, friends or relatives had children at particular nurseries, which were then chosen. In one case, one young mother had attended the nursery herself as a young child. Mostly they visited just one or two nurseries, often not doing so before they were offered a place. Blau \& Currie (2004) writing in the US comment on the lack of information available to consumers, especially poorer families, from which they could draw in order to assess quality of provision.

Parental engagement with childcare is underpinned by cost. The Daycare Trust notes in its 2008 Childcare Costs survey, that the typical cost of a full-time nursery place for a child under two is $£ 159$ a week in England, over $£ 8000$ a year, a rise of nearly 5 per cent on last year. In London the cost of a nursery place is much higher - typically $£ 200$ a week in London. The highest nursery cost identified in the 2008 survey was $£ 436$ a week, over $£ 22,000$ a year. Clearly financial issues were particularly acute for the working class families with whom we spoke, and many local (private) providers were out of reach. Where there were instances of dissatisfaction - and seven working class parents expressed substantial unhappiness - there was little evidence of exit, with only one of these families changing provider. Options were very limited, and cost played a big part in this. One anxious mother describes her search for alternative care,

Mother: [Private nursery] was two hundred and ninety-five pounds. And the price list said two hundred and ninety-five pounds and I actually phoned them up and said, 'Is that a week or a month?' and they said, 'Well, it's a week' as if I was off another planet. So, yeah..

Father: [interrupting] Gold star tuition apparently.

Mother: Because that's another thing, [current nursery] is one of the cheapest nurseries around (£167 p.w). (Isabel and Mike, white parents, participants in the working class project, Battersea (B) 
contribute up to $70 \%$ of fees (see also Lewis 2003). Having to fund the remaining $30 \%$ or more, limited these parents to the cheaper state provision, as we have shown here ('I was just going through all the nurseries in the area, and that one [chosen nursery] was one of the cheapest' (Lauren, black lone mother, participant in working class project, B). The Daycare Trust survey points out that the current average award through the childcare element of the Working Tax Credit is $£ 48.45$ a week, although many of our respondents received the full entitlement. Errors in benefit payments from a notoriously complex system, caused considerable stress to those individuals who had experienced them.

\section{Choosing safety}

Whilst possession of financial resources was an obvious difference between the middle class and working class groups, a less expected difference was their approach to nurseries. The assumptions made by the interviewees, their common sense understandings about 'appropriate' provision, were very different between the two class groups. Concerns about different types of care elicited some of the most emotive language in the interviews. The working class mothers' anxieties and disapproval focused on 'stranger' childminders, and those of the middle class mothers on babies in nurseries. The working class parents were more fearful around their children's physical safety than their middle class counterparts, and commonly opted for nurseries, rejecting childminders unless they were previously known to them. This was striking throughout the sample (see also Vincent \& Ball 2006, Vincent et al 2008a). One lone mother had a child at nursery part time and the boy was also cared for by his grandparents who lived across London. The long journey is preferable to:

'hav[ing] him with strangers, and you've got to make a sacrifice, do other things, I'd rather make the sacrifice than to have him with strangers' (Moira, white, lone mother, SN. Participant in working class project)

Another mother who briefly considered childminders said,

When I got the list of childminders and looking through it, I'm thinking, you know, because I didn't know if I could trust them, I didn't know if...You know I was frightened for him to go to somebody and you know, 
you hear all the stories about shaking babies and things like that $[\ldots]$ There was one [on the list] she was a friend of a friend that I work with and I knew of her...but she didn't have any places... So that's when I had to consider people I didn't know... (Claire, black lone mother, participant in working class project, $\mathrm{SN}$ )

And as a result, Claire chose a nursery. Childminders seemed to be perceived by many of the working class parents as an unregulated group - which is not now the case - whereas the institution of a nursery was perceived to be much safer, precisely because it was clearly a regulated public space:

You don't know who these people are [childminders]. But nurseries and that employ people, and they have safety checks on those people so I feel it's not exactly a total stranger because they're checked out before they are employed and they have references and that sort of thing. So in that way I would trust them (Andrea, B. white young lone mother, participant in working class project)

I definitely wanted her [daughter] to be in a nursery rather than a childminder. I'm not hot on childminders. None of my kids went to childminders, they all went to my mum's or nursery... You see the nursery workers, they're trained, they've got qualifications, they're always someone supervising on what they are doing. They can't be supervised in the home so that's what I feel about childminders, as well as friends. My mum would have been fine. Only my mum..but she's older now so she cannot cope yeah? (Jill, black lone mother, participant in working class project, $\mathrm{SN})$.

One of the three mothers we had in the working class sample who used a childminder emphasised that she chose her carer because she knew her well, and without that prior knowledge would not have left her child with one individual. It is interesting to note the importance of media 'horror stories' here. There is a fear of neglect and even abuse, and a sense of not knowing and not trusting individuals to act responsibly in a 
private space. The public space of nurseries is by contrast open to scrutiny, as the workers are policed by each other.

A majority of the middle class parents, however, (54\% in Battersea, and $70 \%$ in Stoke Newington) chose nannies or childminders for their under threes, with nurseries becoming more popular for children in the immediate pre-school period (3-5 years) due to the perceived intellectual, creative and social advantages offered by a nursery environment for this older age group. They were far more likely than the working class parents to emphasise the importance of small, intimate care spaces, especially for the under threes. In fact, in Stoke Newington there were three examples of small co-operative crèches offering day care, established by parents in order to achieve the informal, intimate and personal care they found to be lacking in other private and state nurseries in the area. In this, parents are following the dominant ideology emanating from public policy in the post war period which has accorded normative status to care in the home by the mother (Gregson \& Lowe 1994, also Dahlberg et al 1999). This valuing of home based care was seemingly not shared by the working class mothers in paid work, who made extensive use of nursery care for their babies and young children (Out of the 42 mothers in the working class sample who were either in paid work or studying, $61 \%$ of those had their children in full time nursery).

However, a majority of the middle class mothers in our first project were uneasy with the idea of group daycare for babies and toddlers. To give just two examples here.

I hadn't gone round nurseries, but I kind of knew it wasn't an option I was keen on...I know there are great nurseries, but I didn't like it was really the concept I didn't like. I didn't like the idea of warehousing....I think warehousing a lot of babies together in a room didn't really seem particularly healthy to me. I don't think from a social point of view it was a particularly natural state of affairs having 12 babies in a room with four adults...Too many people, too many babies... That doesn't seem to me to be a particularly natural way for small children to be raised..... There's a lot less chance of a child being battered in a nursery [but] I thought there was quite a high chance of them not getting what I would think of as appropriate love and attention...People who seem to choose nurseries seem to choose 
them from a safety angle and because, I don't know how to describe it, but from a jealousy angle. They didn't want one individual forming a close bond with their child... but I think if you're working 5 days a week, actually you do need another mummy while you're at work, and that might be painful to admit...[but] why would you want your children to have anything less than a mummy? (Isobel, B. white, with partner, participant in middle class project)

This quotation illustrates the way in which one woman and one or more children in her home is seen as the most appropriate, indeed 'natural' form of care for small children. Angie and Kathryn echoed Isobel's feelings about nurseries:

She was 6 months when I went back to work, she was only just sitting up, I just didn't feel comfortable with her going there [day nursery] so I felt like she needed one to one care. I just didn't feel like I wanted her to be in that kind of institutional environment, no matter how nice it was...It's just the routine and environment that's imposed upon them (Angie, SN, white, participant in middle class project)

I just thought [pre-children], a nursery - it's there, it's easy, it's cheap, to be honest. That was the main presumption. And round here there just aren't very many childminders, or they're very difficult to find. So, that wasn't really on the, the list at all. It was [private day nursery chain] which we chose. And it just, when it came to it, she just didn't settle at all. And I didn't really like it. The, I think it was when I looked at it as a nonparent- when I looked at it as a parent I felt very differently about - and she was quite young, she was five months - and I just felt it wasn't actually right for there to be this number of, sort of, little babies in this room and, you know, not really enjoying it at all. And certainly my older one, she just would not- she really disliked it, she screamed as soon as she went in, sort of thing. So, we just decided [after two days] it wasn't gonna work. And thank goodness for that (Kathryn, B. white, with partner, participant in middle class project) 
These mothers tended to stress the risk of emotional neglect in nurseries whereas for the working class mothers the primary concern was the possibility of physical neglect or harm from childminders. It was very clear that the working class respondents distrusted, even feared, unknown private spaces (such as a childminder's house), and individual, unknown carers (Lowe \& Weisner 2004 also find fears of 'stranger' carers in the US amongst working class families). This lack of social trust accords with $\mathrm{Li}$, Savage and Pickles' (2003) findings that working class respondents are less likely to be socially trusting than those who are middle (service) class. In relation to this, we have written elsewhere about the working class respondents' perceptions of dangers arising from unknown 'others' in their immediate neighbourhoods (Vincent et al 2008b). Rothstein \& Uslaner (2005) raise wider questions on this point, arguing that social trust is lower in countries where economic equality and equality of opportunity across the population are also low.

No-one in the working class sample employed unregistered carers. By contrast, we found, in Stoke Newington, one of our London localities, a significant use of the 'grey market' of unregistered carers by middle class mothers. Such usage involves a high degree of trust of unknown others.

I put an ad out in Church Street. I just put an ad up [laughing]. I just leafleted kind of round the local area. [...] I just thought I'd see if anything came my way and it was an incredible response. Really, really quick response. [...] We got about 12 people really quickly ringing up, of whom I'd say 7 or 8 were completely barking. [...] Maybe I'm exaggerating. There were a couple of chancers who were sounding... a couple of students who couldn't back up with references, that kind of thing. And then [carer] was the first one I actually met and I just really liked her, and really trusted her instinctively and then I phoned up the people she was working for, she was already working for someone else, looking after 2 boys. [....] She was a student, she wanted cash. It's all been done on trust and it has worked. (Anna, white, with partner, participant on the middle class project, $\mathrm{SN})$. 
When I decided I wanted a childminder because I wanted to start work part-time again... I just phoned around to people I knew and I think some people from a Yoga Class, ante-natal, yeah, and I said, "Do you know of anyone who's available for some part-time work?" and someone I didn't know, a friend of a friend, said that she had a lodger who'd just arrived from Brazil. She could vouch for the Brazilian's cousin, who's an old friend of hers, shall she bring her around? [.....] It was a good thing that they started out at 8 months [the baby's age] because when she first arrived she spoke no English. So all I had to go on was the way she related to [baby] directly. I mean obviously he was a little baby at the time, he could crawl, but... and I thought she was good so we started. I did actually ask if she had any training in childcare, and the answer through interpretation was "No". But she had a degree from Brazil in catering and hospitality and stuff like that and she's worked in a hotel where she was responsible for the nursery, and she's been absolutely brilliant (Grace, white, with partner, participant in middle class project, $\mathrm{SN})$.

Here we see resources of cultural and social capital at work in the mothers' self confidence. The middle class mothers cited here are secure in their ability to use their social networks to obtain contacts, judge the innate, 'natural' qualities of a 'good' carer, and weed out the 'chancers'. These respondents do not appear to need the formal reassurance of carer qualifications.

Again, in contrast, some respondents in the working class project did not feel comfortable leaving their child with another carer, even if in a formal regulated setting, and cited lack of trust as the explanation for this. One young mother whom we met at a Sure Start parents' group, suggested no-one would care for her daughter as she did:

I'm the mum, I don't leave her. Anyway she's at the clingy stage, first it was me actually [feeling 'clingy'] and then it started to rub off on her..I am going to try and leave her with [friend from group], but when I leave her, I keep checking on her. [I have left her in the Sure Start] crèche about 
two or three times which was OK, but I kept checking on her to make sure there wasn't anything going on that I didn't want... Like people leaving her with small things about that she might pick up, or giving her food when I don't want her to be fed, or when she's standing because they might think she's OK and then she might fall. Just feeling protective (Katie, young white, lone mother, B. participant in working class project)

Another at-home mother commented,

I know everyone is checked and everything - well some people ain't checked. And that has always worried me that I might unfortunately get one who's slipped through the net. And I'd never forgive myself . I mean with school I've got no choice, once they hit five they have to go to school, I can't do nothing about that much as I think 'oh dear'. All these people they keep coming on TV, that have all slipped through nets and things like that (Liz, white mother, divorced, B)

Here again the influence of the media is key in creating the impression that children are intensely vulnerable to abuse from unknown 'others', and that current safeguards are insufficient (Furedi 2001)

\section{Choice and primary schools}

Our data on choice of childcare showed few marked differences within the sample, between the choice-making behaviour of the working class respondents who used childcare. Our main point of comparison was with the attitudes and behaviours of our middle class sample. In the second half of the paper, focusing on choice of school, we take a slightly different approach. There is a large qualitative literature on middle class choice of school (e.g. Gewirtz et al 1996, Ball 2003, Brantlinger 2003, Butler with Robson 2003, Butler et al 2007, Raveaud \& Van Zanten 2007, Reay et al 2007), most of it focused on secondary transfer (although see Noreisch 2007). This literature identifies the ways that, despite the differences across middle class fractions in values, actions and behaviours, these families are generally skilled consumers, possessing and able to activate appropriate resources of economic, social, and cultural capital, to help them realise, as far as possible, their preferences for their child's schooling. 
Working class families as a whole have generally been counter-posed to and contrasted against the degree of strategising and planning undertaken by middle class families. However, we did find differences amongst our working class sample, concerning choice of school. In the current mixed economy of childcare provision, working class families were constrained by cost from venturing outside the apparently homogeneous (in these two localities) state sector. Where compulsory education was concerned the state sector was much more obviously diverse, with a major distinction for the working class respondents being secular/faith schools. 19 out of 70 working class respondents had chosen or wished to chose a Catholic or Church of England school, another family was considering an Islamic secondary school and none of the three Ultra-Orthodox Jewish respondents would have chosen anything other than a school within their community.

We asked parents about choice of school, as one part of a lengthy interview schedule which, as well as focusing on choice and experiences of childcare, also asked about paid work, and managing domestic responsibilities. We phrased our question around primary school choice, but those respondents who had older children often talked in detail about transfer to secondary schools. We have made it clear in the examples below to which phase of schooling respondents are referring. Our sample of 70 families broke down into 3 main categories: willing choosers, default choosers, and community choosers.

\section{Willing choosers}

There were 35 willing choosers (out of 70 families). We are defining 'willing' here as evidence of activity, as collecting information, identifying a desired school and being able to discuss the feasibility of getting a place there. The term is not meant to suggest 'successful' choosing. Indeed, even the willing choosers, despite their best efforts often struggle to maintain a tenuous grasp on the choice process. Kim probably comes closest to the model of middle class choosing. She moved her son to a primary school she describes as 'middle of the road' in terms of test results, but where 'he has done really well'. They have visited and were applying for a range of selective state and private schools (and bursaries) for his secondary education. Kim is extremely anxious, based on her observations of the behaviour of the pupils there, to avoid the local nearby secondary school. Negotiating the web of admissions arrangements for 
selective and private schools has been difficult, but they have identified a small number of schools which they liked and, when we spoke, their son was preparing to take academic tests to determine whether or not he will be offered a place. Support for their son in preparing for these tests, has not come from private tutors, as would be expected in a middle class household, but, serendipitously, from the class teacher at the primary school.

The teachers have been really good. So this year, because he's obviously got these tests, he got an example paper through for Dulwich [prestigious independent school], and he done it and he wasn't sure about a lot of the stuff on it and he started to worry about it. So we sort of said to him, "Right, well, take it to your teacher and say to her, 'Look, this is what I've got to do. Is there any way you can help?'” So she gave us a load of- she gave us a load of tests, example test papers for him to do, quite big bits and, you know, since then he's been sitting through them and then we'll have the answer sheet and then we go through it. So it's practice (Kim, white, living with partner, B.)

This encapsulates the situation of many of our willing choosers. They lack one or more capitals - social, cultural or economic - in the form which would allow them to increase the chances of realising their preferences. Kim and her partner could not afford a private tutor, indeed it is not clear that they recognised private tuition prior to the tests as a possibility. Instead they turned to the familiarity of the primary school and, by chance, received considerable support from an individual there.

Veronica used the league tables to identify two of the highest performing primary schools in her area, visited them and, despite the 'posh and snobby' parents there, decided she would apply to both. When we spoke she was living in a flat likely to be slightly too far away from either school to gain a place, but there is no alternative plan to be made. She did not have the resources to move closer to the schools (both in expensive, gentrified areas).

You have to try it, do you know what I mean, because it's my choice and they told me I've got a choice, do you know what I mean? So I'm just hoping she 
gets into one of those schools. I'm praying, really. That's all I can do, I mean. But if she doesn't, that's how it goes, that's how it goes, you know (Veronica, black lone mother, B.)

Enthusiasm for choice is, as here, often tempered by fatalism that arises from realising there is little one can do if the preferences expressed are not met.

Sometimes the departure from the classic middle class chooser model came from a lack of knowledge about the education system. A minority were clearly struggling to understand the systems and procedures involved. Andrea (young, white lone mother, B.) is hoping for an arrangement that sounds like the old Assisted Places Scheme or a voucher system,

Ideally, I'd like her to go to a private school but obviously I haven't got the funding for it. But I thought maybe that if I applied to the council they might pay some of the [inaudible] they pay for a normal school then maybe I could make up the rest to send her.

Several people commented that school places were scarce and felt that 'putting the children's names down' early would help secure a place in a state school. Here Mike, father of a 22 month old, is corrected by Isabel, his wife

Mother: she'll never get into [school X], she'll never get into [school $\mathrm{Y}]$, the one next to the brewer's [....].

Father: Well, if we put her name down now she could do.

Mother: No, she won't (Isabel and Mike, white parents, B).

Recent migrants may be keen to have their children succeed at school, but are also particularly likely to feel they have little purchase on the education system in general and choice in particular, as one of our examples below shows. Stefano is from Italy and his wife from Croatia. His account clearly reveals his confusion and anxiety, 
around accessing a place for his child, feelings that other migrant families also expressed to us.

The only thing, you know, with some of them [schools] there is a long list here and there, so basically, she should have been down when she was as I said, you have to plan a long, long time - when she was one or two. Because the waiting list, you know, they got thirty openings and there is a hundred and fifty applicants. Then it doesn't make.... And then you're like in a queue system so therefore if someone then drops out then you're automatically going higher and [inaudible]. And especially the older, you know, the higher schools, the primary and secondary, there's less chance for them to get in that particular school. Because there is not enough space. And then, obviously, you want the best for your child and everything and you start reading the reports, the books, what high score in this and that, and it's so confusing, you know. [....] There is huge leaks within the system of the education and everything. The result - I don't see much result anyhow. I mean, if you try to study those papers and say, oh, what high score they are that one. Well, what do I know? Science, yes, up to the- but, you know, there is nothing which is for everybody to read black and white. And I consider myself as a fairly educated here and there, and I can imagine, you know, somebody who's not as educated, or are under-educated, would not understand it.

Other families in the sample assumed their child would go to the nearest school without considering other possibilities, and we have termed this group 'default choosers'.

\section{Default choosers}

12 families fell into this category. There is some overlap here with the third group, community choosers, in that the nearness of the school is important to both groups. However, unlike the community choosers, the default choosers did not mention a particular connection with the school they were about to or had chosen. It is certainly not the case that these parents were uninterested in their children's education, rather that they expected all (or at least most) schools to be able to competently educate their 
child. They differ from those willingly and actively attempting choice in that they do not see differences between institutions in the vivid hues that these other parents do.

But it's all about the child. If the child- if you send your child to school to learn and that child wants to learn that child will sit down and learn (Chanelle, young black, lone mother, $\mathrm{SN}$ )

There's always worries about schools so, you know, you can't win. There's worries about everything but, you know... (Berenice, black lone mother, B.)

And I think if the child, you know, as far as their education is concerned it's up to the child, I think, what they, you know, what they want to do is what they're going to do. I mean, you could get the best teacher, the worst teacher, it's up to you individually if you're going to study and do, you know, well, or you're not going to study and not going to do well. And what can you do? But in Hackney I just think, 'Oh well, we've just got to pray for the best,' basically (Moira, white lone mother, SN)

I think all of them [schools] are the same [.... Y Yes, [school $\mathrm{x}$ is] where I want [daughter] to go, because she's my...I've got a niece that's there and it would be easy help to get [daughter] picked up [....] I've heard that it's a good school; it's a small school, you know, and the main thing is the practicality of getting her picked up. Because with me and schools I heard it's a good school, it's not brilliant on the tables but the tables are...I don't agree with the tables, they're no good, they're not true, you know. So I think most teachers in most schools do try their best. (Jill, black lone mother, $\mathrm{SN})$

[Chosen school is] the closest to me and I always knew there is a school there. And once I went and I asked them, and they said I have to put her name down after [child is] three [years of age]. ....And they send me the application form and I filled everything, like phone bills and all the things that they want [as proof of address]. Everything is different now, much 
harder. They're very strict....I didn't know any other ones. And after that I heard about [another school], one of the mums said to me, but it was too late it was no good [....] [At work ] they always say [chosen school is] very nice, the head is very nice (Nisrine, Middle Eastern migrant, with partner, SN).

These parents refuse choice, expecting the nearest school to be satisfactory. However an individualised responsibility for learning is still accepted: if the child fails it is the fault of their inattentive/uninterested self, and not that of the institution. Another mother notes the fundamental need for practicality in choice.

The reason is the school is near, because when my bigger one started the other one was still small. So, you know, sometimes the bus is so crowded, and you have a pushchair with the other babies, and...no. But this school is near, and we know the people, every parent, every teacher, the kids, the teachers, yeah, we know them so why I go to other schools, to look other schools? (Bolu, black African, with partner, B.)

Her words illustrate the challenge of moving around on public transport with small children, and also reveal the overlap between default and the next category, community choosing. As Bolu notes, after attending a school for a while, one becomes part of that school community, knowing the children, parents and teachers and being known by them. Given this familiarity, this sense of being part of a collective and the resulting feeling of security and belonging, why, as she says, would she look at other schools?

\section{Community choosers}

The importance of the familiar in guiding choice is emphasized in our third category. Despite the frequency of 'narratives of decline' (Watt 2006), from our respondents indicating their concern about the behaviour of disreputable and sometimes dangerous 'others' in the locality, many families' links with their localities were strong. $21^{5}$ families fell within what we have termed 'local community chooser'. 14 of those cited

\footnotetext{
${ }^{5}$ For the two remaining families out of 70 , there was not enough information to categorise their choice making.
} 
a personal link with a school (often themselves or their partner's attendance, sometimes a family member from a younger generation) as a reason for choice. Indeed, extended family was central to the lives of most of the 'local' working class families in this study, in coping with the routines and exigencies of life in ways that were not present at all in our previous research on middle class families.

My sister went there, and I went there for a bit ... my cousins went there, my whole family went there ... my mum's name is on the wall (Abeni, black African, lone mother, B.)

It's like my mum went there and my aunts and uncles .. and we went there and my brothers went there, and now my nephew's going there (Taysha, black lone mother, B.)

My sister-in-law's kids go there, that's why [we chose it]. And my sisterin-law, when she always used to go there, and everybody said it's very nice school, it's good school actually (Asma, Asian, with partner, SN) I went there, my brothers and sisters have been there, my mum works there, I know the teachers, so I was very happy with the school ... I didn't really go round and see other schools (Alanis, black, with partner, B.) I would like [son] to go to a Catholic school, because we are Catholics (Valerie, black African, lone mother, B.) What schools? C of E school because we're C of E. (Audrey, black mother, with partner, B.)

Also within this group, as the last two quotes illustrate, are those who did not refer to specific individuals, but rather saw the school they had or were going to choose as somewhere where they would be amongst others like themselves, usually meaning from a particular faith or ethnic grouping. Those who wanted their child to attend a religious school understood, for the moment at least, the type of school to be more important than the particular establishment.

We want to make a simple but significant point here - that for a significant proportion of the families in our study, choice is not straightforwardly the enactment of individual or familial self-interest. Motivations are not that simple or straightforward. 'Choices' are framed by norms, of community and religion and family, webs of social 
relationships continue to be of importance when seeking to 'do the right thing' for children, where doing 'the right thing' is located in concrete circumstances and social contexts 'in which individuals "'move" and act' (Irwin 2005: 122). For some of these families, others 'like us' are sought out in the process of choice both as a means of instrumental reassurance and as an expressive reaffirmation of social ties and social identities. These are not 'classlessly individualised' choices as 'traditional parameters' and ties are still in evidence here and these people do not all simply 'refer to themselves' in their life planning (Beck 1992 p. 87) or attempt to construct 'experimental lives', some important 'collective certitudes' are still in play.

\section{Conclusion}

Threaded through our data are references to the importance of the known, the familiar and therefore the trusted for the working class respondents. Family members are a key resource, whilst they were of marginal significance in the middle class parents accounts of care and education. In the working class parents' accounts of help with childcare from family members, their distrust of home-based carers who were not previously known to them, and the appeal of schools attended by family members or children with the same religious or ethnic identity, we can see the attraction and security of local bonds and family networks (see also Horvat et al 2003). Being able to recognize and 'know' a care or education setting, to feel comfortable with the idea of it, is a key influence in the choice-making of these families on behalf of their children. The aspects of choice-making we have sought to highlight - the practical and the communal - are not represented well, if at all, within choice policies where the logics of individualised families and the maximisation of their self-interest are privileged. However, we wish to argue that, whilst there are significant differences, middle class choice is not as purely individualised and rational as is often presented (Ball 2003). The accounts of our middle class mothers of their choice of childcare are infused with emotion, with chance occurrences and with the influence of choices of 'People Like Us'. Factors influencing choice of schools for many middle class parents include their perceptions of a suitable similar peer group, and the avoidance of disreputable 'others' (Ball 2003, Brantlinger 2005). Ultimately perhaps, 'choice' is simply inadequate conceptually to the task of sense-making here. Too much else is involved. 'Neo-liberal assumptions about markets, choice and quality are simply too crude to cope with the subtleties of the relationship between social class and 
education.' (James et al forthcoming). 'Choice' could be better understood as a signifier for a composite of fears, aspirations, contingencies and constraints, norms, social relations, and routines and obviousnesses that are involved in the relations between families and care settings and schools. However, whilst in theory, and as academics, we can step outside choice, critique it and render it harmless, as a global policy discourse it remains powerful and central to the way in which public sector services are organised, and it demands a particular type of strategic behaviour. Choice policies both require and form 'responsive and anxious consumers' ${ }^{6}$, but this expectation elides the vast differences amongst parents in the possession of the necessary resources and inclination to engage with education and care systems in this fashion. Middle class parents may not all share all the characteristics of the atomised self-interested chooser (Reay et al 2007), but through their plentiful and relevant resources of capital, they have a degree of freedom open to them to choose a logic of choice - that is to shape their choice making to suit their values and beliefs. This is a point eloquently made by Reay and her colleagues who explore the decisions of some middle class parents to choose apparently counter-intuitively, lower-performing, local inner city schools. They note that 'in a stratified system middle class families are in a position to make choices that the market holds up as much less favourable and they can do so without apparent detriment to their acquisition of educational credentials, opportunities and progression,' (James et al forthcoming). In many cases, when it comes to choosing care setting or school, the working class parents in our research have little other choice but the local. However, the benefits of and logic to prioritizing the local and the known is not recognised within policy which calls for strategic and individual enterprise. In these mismatches lie the bases of a specific and increasingly pervasive inequality.

\footnotetext{
${ }^{6}$ Thanks to an anonymous reviewer for offering us the phrase and encouraging us to clarify the point.
} 


\section{References}

Ball, S. \& Vincent, C. (2005) 'The childcare champion?' New Labour, social justice and the childcare market, British Educational Research Journal, 31 (5): 557-70. Ball, S. J. (2003) Class Strategies and the Education Market Place, London: RoutledgeFalmer Beck, U. (1992) Risk Society: Towards a New Modernity. Newbury Park, Sage. Berlinski, S., Galiani S. \& Manacorda, M. (2008) Giving children a better start: preschool attendance and school age profiles Journal of Public Economics 92 (5/6) 1416-1440.

Blau, D. \& Currie J. (2004) Pre-school, day care and after school care: who's looking after the kids? National Bureau for Economic Research Working Paper No.

W10670.

Brantlinger, E. (2003) Dividing Classes. London, Routledge.

Braun, A. Vincent, C \& Ball, S. (2008) 'I'm so much more myself now, coming back to work' - working class mothers, paid work and childcare, Journal of Education Policy, 23 (5) 533-548

Butler T., Hamnett, C., Ramsden, M, and Webber, R. (2007) The best, the worst and the average: secondary school choice and education performance in East London, Journal of Education Policy, 22, (1): 7-29

Butler, T. with Robson, G. (2003) London Calling. Oxford, Berg Carling, A., Duncan, S. and Edwards, R. (2002) Analysing Families: Morality and Rationality in Policy and Practice, London, Routledge.

Chevalier, A., Finn C., Harmon, C., and Vitanen T. (2006) The Economics of Early Childhood Care and Education, Technical Research Paper for the National Economic and Social Forum.

Clarke, J. Smith, N. \& Vidler, E. (2006) The Indeterminacy of choice: political, policy and organisational implications Social Policy \& Society 5:3, 327-336 Dahlberg, G., Moss P., \& Pence, A., (1999) Beyond Quality In Early Childhood Education and Care: Postmodern Perspectives. London: Falmer Press.

David, M. (1993) Parents, Gender and Education Reform Cambridge, Polity Press. Daycare Trust (2007) Annual Review 2007 London, The Daycare Trust.

Daycare Trust (2008) Childcare Costs Survey 2008. London, The Daycare Trust. Dermott, E. (2008) Intimate Fatherhood London, Routledge.

Duncan, S., Edwards, R., Reynolds, T., \& Alldred, P. (2003) Motherhood, paid work and partnering: values and theories, Work, Employment and Society, 17 (2): 309-330. Duncan, S., Edwards, R., Reynolds, T., \& Alldred, P. (2004) Mothers and childcare: policies, values and theories, Children and Society, 18: 254-65.

Gordon, C. (1991) Government rationality: an introduction in G. Burchell, C. Gordon and P Miller (eds.) The Foucault Effect. Hemel Hempstead: Harvester Wheatsheaf. Gregson, N., \& Lowe, M. (1994) Servicing the Middle Classes: Class, gender and Waged Domestic Labour in Contemporary Britain. London, Routledge.

Heckman, J. \& Masterov D. (2007) The productivity argument for investing in young children, Review of Agricultural Economics 29 (3) 446-493.

Irwin, S. (2005) Reshaping Social Life, London, Routledge.

James, D. et al (2008) Neoliberal policy and the meaning of counter-intuitive middle class school choices. Draft paper

Lewis, J. (2003) Developing early years childcare in England 1997-2002: The choices for (working) mothers Social Policy and Administration 37 (3) 219-238. 
Li, Y, Savage, M \& Pickles, A. (2003) Social Change, Friendship and Civic Participation Sociological Research Online, 8, (4), $<$ http://www.socresonline.org.uk/8/4/li.html

Lowe, E. \& Weisner T. (2004) 'You have to push it- who's gonna raise your kids?': situating child care and child care subsidy in the daily routines of lower income families, Children and Youth Services Review, 26 (2) 143-171.

McKie, L., Bowlby, S. \& Gregory, S. (2001) Gender, caring and employment in Britain, Journal of Social Policy, 30 (2): 233-58.

Meyers, M \& Jordan, L. (2006) Choice and accommodation in parental child care decisions Community Development: Journal of the Community Development Society, 37, 2: $53-70$

Noresich, K (2007) School catchment area evasion: the case of Berlin, Germany, Journal of Education Policy, 22, (1): 69-90

Olssen, M. (1996) In defence of the welfare state and publicly provided education: a New Zealand perspective, Journal of Education Policy, 11 (3): 337-62

Raveaud, M \& van Zanten, A. (2007) Choosing the local school: middle class parents' values and social and ethnic mix in London and Paris, Journal of Education Policy, 22 (1): 107-124.

Reay, D. et al (2007) 'A Darker shade of pale?' Whiteness, the middle classes and multi-ethnic inner city schooling, Sociology 41 (6): 1041-1060.

Rothstein, B. and Uslaner, E. (2005) All for All: Equality and Social Trust. LSE Health and Care Discussion Paper No. 15. Available at Social Science Research Network : http://ssrn.com/abstract=824506

Vincent, C. \& Ball, S. J. (2006) Childcare, Choice and Class Practices. London, Routledge.

Vincent, C., Ball, S. J. \& Braun, A. (2008b) 'It's like saying “coloured"': understanding and analysing the urban working classes. The Sociological Review 56 (1): 61-77.

Vincent, C., Braun, A. \& Ball, S. (2008a) Childcare, Choice and Social Class, Critical Social Policy, 28, (1) 5-26

Watt, P., (2006), Respectability, roughness and 'race': neighbourhood place images and the making of working class social distinctions in London, International Journal of Urban and Regional Research, 30 (4): 776-797.

Wossmann, L. (2008) Efficiency and equity of European education and training policies, International Tax and Public 


\section{Appendix}

Finance 15 (2) 199-230.

Occupational categories of working class respondent mothers

\begin{tabular}{|l|c|c|c|}
\hline NS-SEC & $\begin{array}{c}\text { Stoke Newington } \\
(\mathbf{n = 3 4 )}\end{array}$ & $\begin{array}{c}\text { Battersea } \\
(\mathbf{n = 3 6})\end{array}$ & $\begin{array}{c}\text { All Mothers } \\
(\mathbf{n = 7 0})\end{array}$ \\
\hline Class 1 & 0 & 0 & 0 \\
\hline Class 2 & 5 & 4 & $9^{*}$ \\
\hline Class 3 & 8 & 11 & 19 \\
\hline Class 4 & 2 & 1 & 3 \\
\hline Class 5 & 0 & 0 & 0 \\
\hline Class 6 & 6 & 11 & 4 \\
\hline Class 7 & 3 & 1 & 11 \\
\hline Class 8 & 6 & 5 & 7 \\
\hline Unclassified & 4 & 3 & 47 \\
\hline
\end{tabular}

- Compared to mothers in the middle class study, mothers categorised as Class 2 had very different occupations, e.g. a betting shop manager in this study, versus a drama therapist in the middle class study.

\section{Key: NS-SEC Classifications}

Class 1

Class 2

Class 3

Class 4

Class 5

Class 6

Class 7

Class 8

Unclassified
Higher managerial and professional occupations Lower managerial and professional occupations Intermediate occupations Small employers and own account workers Lower supervisory and technical occupations Semi-routine occupations Routine occupations Never worked and long-term unemployed Includes students, not enough information for categorisation and unknown 